\title{
Erratum to: Potted Review of Economic Theory: The Complex Evolving System
}

\author{
Benjamin Aaron Rosen
}

\section{Erratum to:}

Chapter 1 in: J.-P. Close (ed.), AiREAS: Sustainocracy

for a Healthy City, SpringerBriefs on Case Studies

\section{of Sustainable Development, DOI 10.1007/978-3-319-26940-5_1}

The editor Mr. Jean-Paul Close would like to get his name removed from Chapter 1 of the book.

Open Access This chapter is distributed under the terms of the Creative Commons Attribution-NonCommercial 4.0 International License (http://creativecommons.org/licenses/by-nc/ 4.0/), which permits any noncommercial use, duplication, adaptation, distribution, and reproduction in any medium or format, as long as you give appropriate credit to the original author(s) and the source, a link is provided to the Creative Commons license, and any changes made are indicated. The images or other third party material in this chapter are included in the work's Creative Commons license, unless indicated otherwise in the credit line; if such material is not included in the work's Creative Commons license and the respective action is not permitted by statutory regulation, users will need to obtain permission from the license holder to duplicate, adapt, or reproduce the material.

The updated original online version for this book can be found at 10.1007/978-3-319-26940-5_1

\footnotetext{
B.A. Rosen ( $\square)$

University of Haifa, Haifa, Israel 